\title{
An Empirical Study on the Effect of Yu'ebao to the Deposits in Chinese Commercial Banks
}

\author{
Jing Li \\ School of Economics, Jinan University, Guangzhou, China \\ Email:bsljmz@163.com
}

Received 2 December 2015; accepted 22 December 2015; published 25 December 2015

Copyright (C) 2015 by author and Scientific Research Publishing Inc.

This work is licensed under the Creative Commons Attribution International License (CC BY).

http://creativecommons.org/licenses/by/4.0/

(c) () Open Access

\begin{abstract}
Since the launch of Yu'ebao, the scale of it has reached up to 574.16 billion RMB by the end of June 2015 and has become the fourth greatest international monetary fund. The rapid expansion of Yu'ebao has brought about a knock-on effect on commercial bank. This article introduces panel regression mode to testify what the beingness of impact of Yu'ebao on saving deposits of commercial banks based on the perspective of saving deposits of commercial banks, as well as to make an comparative study of what the impact of Yu'ebao on different types of commercial banks, and try to come up with corresponding policy suggestion in the end based on empirical findings.
\end{abstract}

\section{Keywords}

Yu'ebao, Commercial Banks, Deposits, Empirical Analysis

\section{Introduction}

As the rapid development of internet financial industry and newly diversified financial products, the collaborative product Yu'ebao of Alibaba Group and Tianhong Asset Management is the most successful one in June 2013. It has gradually entered into people's living and it has attracted great attention from all walks of life. As a brand-new internet financial product, the capital scale of Yu'ebao struck 10 billion RMB within only one month by virtue of its high profits, low entry threshold, convenience operations and excellent fluidity etc merits, and it attracted a great sum of current capital in the short run. At the same time, as the accumulative users and expanded scale of Yu'ebao, this kind of new-pattern financial method has gradually changed the populace's concept to saving deposits. For traditional commercial banks, this kind of latest internet financial product like Yu'ebao has taken away partial saving deposits from commercial banks, while saving deposits business is indeed the core activity for them. Therefore, making a deeper research of the impact of Yu'ebao financial products 
on saving deposits of China's commercial banks and analyzing how commercial banks will defend against the loss of saving deposits and how to set out long-time strategy of sustainable development in the face of Yu'ebao internet financial products are of great significance to the future of China's commercial banks.

\section{Review of the Literature}

In addition, the success of Yu'ebao not only triggers the upsurge of social discussion, but also stimulates the enthusiasm of economists to discussion of Yu'ebao, especially the fierce discussion on whether Yu'ebao makes an impact on banking industry or not. Sheng Songcheng and Zhang Xuan hold the opinion that Yu'ebao, essentially, is a policy arbitrage, fortified supervision shall be made to ensure a fair and orderly financial market [1]; XiePingze believes that Yu'ebao cuts down partial margins and profitability of traditional commercial banks by altering deposit structure of banking industry. However, it will not make an effect on loan interest rate, and not mention to drive up the financing cost of all society [2]; Qiu Xun believes that the current deposit flow of China's commercial banks will not only copy the tendency of America's deposit money of commercial banks, but also will be shortened under the impact of internet finance on the process and time [3]; Niu Wenxinetc points out that Yu'ebao pushes up the overall financing cost of banking system, which will be replaced [4]; Gao Shanwen thinks that Yu'ebao weakens the channel monopoly of traditional banks and breaks the division of financial market and reduces the mobilization costs of deposit, which will make more low-income earners benefit from it [5]; Nevertheless, these previous studies are mostly based on theory to analyze, but rarely to explain if this kind of effect does ever exist and its degree with empirical analysis, it weakens the persuasion of conclusion in some ways. Therefore, this article incorporates available data and employs empirical analysis to analyze and studies the impact of Yu'ebao on saving deposits of commercial banks, consequently to make a deeper exploration.

\section{Theoretical Analysis}

Current deposit is the principal liability business for commercial banks. It gains inexpensive high quality deposits depending on institutional advantage all the time, and gains generous profits by the means of loan and interest margin. However, in recent years, the rapid development of internet financial industry makes effects on the pattern of cheap bank deposits and makes an impact on business of saving deposits of traditional banks, which result in the loss of partial saving deposits for commercial banks and appears phenomenon of the loss of users.

Yu'ebao depends on Alipay, which is a third party payment platform with the function of deferred payment, the unliquidated capital will accumulate on the third party payment platform as a kind of disguised current deposit to keep in Alipay. To some extent, it divides up partial saving deposits of commercial banks. At the same time, Yu'ebao attracts piles of customer service groups because of its high profitability, high fluidity and redemption convenience. People have gradually realized that they would rather put the capital into financial products of low risk with high profits than put it into current account. It specifically reflects in following aspects: in the aspect of fluidity, the fluidity of Yu'ebao is much better compared to the ones of financial products of commercial banks. Yu'ebao may achieve $\mathrm{T}+0$ pattern, namely "buy today, redeem today", which is very convenient. However, most of financial products of commercial banks are geared to close-ended funds, namely "no redemptions without the due of deadline”. In the aspect of profitability, the earnings of Yu'ebaois not only higher than current deposit, but also surpasses many of homochronous funds and bank financial products, the earning of Yu'ebao makes a daily give-out pattern, and seven-day annual yield is commonly higher that reaches up to 5\% or so. Nevertheless, there's no comparison for current deposits of commercial banks, the emerge of Yu'ebao provides high yield investment and financing channel for grass-root class. In the aspect of investment risk, the product of Yu'ebao is rather level-headed because of Alibaba e-commerce platform being its powerful support. Alibaba makes use of big data analysis to control the risk, and as the emergent novelty, if there's appeared to be a major risk, it will be lack of the trust of the mass in consequent development. As a result, the current deposit of commercial banks suffers from a certain impact.

\section{Statistical Analysis}

\subsection{The Empirical Analysis of Yu'ebao to Saving Deposits of Commercial Banks}

\subsubsection{Variable Selection}

Dependent variable is the saving deposits of China's commercial banks. The major index to measure saving de- 
posits of commercial banks is the total amount of saving deposits, but the article thinks that the total amount of saving deposits is an absolute value with a rather enormous gross, while the effect of Yu'ebao on saving deposits business of commercial banks mainly reflects the effect on the growth of saving deposits. Therefore, the article selected the increasing rate of saving deposits as dependent variable.

The independent variable what the article explains is Yu'ebao, the current index to measure Yu'ebao mainly includes ten thousand accrual daily and seven-day annual yield. Ten thousand accruals are an absolute value, in consideration of the coherence of each variable in positivism model. The article selected seven-day annual yield as an absolute value for measuring Yu'ebao, expressed by yebsy.

There are many factors which will affect saving deposits amount of commercial banks. The article thinks that eternal factors include consumer expectation, stock yield, CPI and average family income, internal factors include the rate of bank charges and distribution channel of banks (namely affiliated agency of banks) etc.

Consumer expectation: consumer expectation refers to the impulse tendency of an individual to consumption under the circumstances of expected market brisk, increasing income and rising prices etc. According to Keynesian theory of consumption, consumer expectation is a key factor of affecting consumer savings; commonly-used index to measure consumer expectation includes consumer confidence index, consumer satisfaction index and consumer expectation index. The article selects consumer expectation index as the measurement index for consumer expectation, expressed by CEI.

Stock yield: when stock yield is in a rather higher level, consumers will transfer saving deposits from a bank to use on stock investment; when stock market is in a downturn, they will choose to save up, therefore, stock yield is a key factor to affect the saving deposits of commercial banks. The article selected growth rate of Shanghai securities composite index as the measurement index of stock yield, expressed by szzszzl.

CPI: CPI refers to consumer price index, the article thinks that CPI has a dual influence on consumer saving deposits: on the one hand, the rising of CPI represents rising prices, in order to purchase a single product, the consumer will be required to invest more money on it, which has a certain negative influence on saving deposits. On the other hand, the rising of CPI representing the macro economy is rather prosperous. The increasing consumer income has a positive stimulatory effect on saving deposits.

Average family income: average family income has a positive effect on savings. However, the data sample of article is quarterly data, while average family income is annual data. Therefore, the positivism model of the article will not consider the effect of this factor on saving deposits of commercial banks.

Rate of bank charges: generally speaking, the rate of bank charges has a negative effect on absorbing saving deposits, but the deposit of four big state-owned commercial banks take up over $60 \%$ total amount of domestic commercial banks. The handling charge of state-owned is generally higher than the ones of other stock-holding banks, thus the article thinks that the effect of bank charges on saving deposits of commercial banks is uncertain, the article selected the rate of bank charges as the measurement index for bank charges, expressed by sxfl.

Channel of distribution: the channel of distribution of article mainly refers to the affiliated agency of banks. Affiliated agency has a positive effect on absorbing saving deposits for commercial banks. The article selects the quarterly average growth rate of affiliated agency of commercial banks as the measurement index of channel of distribution, expressed by jgzzl.

Detail indicators were chosen as the Table 1.

\subsubsection{Describing the Data}

The article selects the quarterly date of ICBC (Industrial and Commercial Bank of China) Bank of China, Agricultural Bank of China, CCB (China Construction Bank), Bank of Communications, China Merchants Bank, China Citic Bank, CMBC (China Minsheng Banking Corp. Ltd.), Shanghai Pudong Development Bank, Industrial Bank, Ping An Bank, CEB (China Everbright Bank), Bank of Ningbo and Bank of Beijing from June 2013 to June 2015 as research object, the saving deposits, fee and commission income and affiliated agency date of banks are derived from relevant annual report revealed quarterly of each bank, CPI, consumer expectation index and stock yield are derived from CEInet.

\subsubsection{Model and Results}

To testify the empirical effect of Yu'ebao on saving deposits of commercial banks, the measurement model of regression model is introduced in the article as follow: 
Table 1. Selection of indicators.

\begin{tabular}{|c|c|c|}
\hline Explained variable & Explanatory variable & Note \\
\hline \multirow{6}{*}{$\begin{array}{c}\text { Growth rate of saving deposits = (saving } \\
\text { deposits amount of current } \\
\text { season-saving deposits amount of } \\
\text { previous season)/saving } \\
\text { deposits amount of previous season }\end{array}$} & Seven-day annual yield of Yu’ebao (yebsyl) & -- \\
\hline & Consumer expectation (CEI) & -- \\
\hline & Stock yield (szzszzl) & $\begin{array}{c}\text { Geometric mean of growth rate of } \\
\text { Shanghai securities composite index } \\
\text { of each trading day of March, June, } \\
\text { September and December }\end{array}$ \\
\hline & Consumer Price Index (CPI) & -- \\
\hline & Rate of bank charges (sxfl) & $\begin{array}{l}\text { Geometric mean of primary } \\
\text { handling fee rate of deposit } \\
\text { business in each bank }\end{array}$ \\
\hline & $\begin{array}{l}\text { quarterly average growth rate of affiliated agency of } \\
\text { commercial banks (jgzzl) }\end{array}$ & $\begin{array}{c}\text { (the number of bank branches in this } \\
\text { quarter-he number of bank branches } \\
\text { in last quarter)/the number of bank } \\
\text { branches in this quarte }\end{array}$ \\
\hline
\end{tabular}

$$
\text { ckzzl }=\alpha_{0}+\alpha_{1} \text { yebsyl }+\alpha_{2} \mathrm{CEI}+\alpha_{3} \mathrm{szzszzl}+\alpha_{4} \mathrm{CPI}+\alpha_{5} \ln \mathrm{sxfl}+\alpha_{6} \ln \mathrm{jgzzl}+\mu_{i t}
$$

Empirical results of this model were shown as Table 2.

Form Table 2, we can know that regardless of fixed effect model or random effect model, the seven-day annual yield of Yu'ebao has a significantly negative effect on growth rate of saving deposits of commercial banks, which testified that Yu'ebao has a flow tendency to saving deposits business of commercial banks, consequently, the outcome of positivism model can be expression by following equation:

$$
\text { ckzzl }=0.07-2.06 \text { yebsyl }+0.21 \ln \text { jgzzl }+0.35 \mathrm{CEI}+\mu_{i t}
$$

\subsection{Differentiation Comparison of Yu'ebao Yield to Saving Deposits of Various Kinds of Banks}

The saving deposits of domestic commercial banks are mainly affected by Yu'ebao yield, growth of agency and consumer expectation index etc factors. Domestic commercial banks are primarily divided into four categories, namely the state-owned commercial bank, joint-stock commercial bank, city commercial bank and rural commercial bank. Is the effect of Yu'ebao on these various kinds of saving deposits of banks accordant? The article will build verification test based on this issue. Based on the accessibility of data, the article primarily selected ICBC (Industrial and Commercial Bank of China) Bank of China, Agricultural Bank of China, CCB (China Construction Bank), Bank of Communications, China Merchants Bank, China Citic Bank, CMBC (China Minsheng Banking Corp. Ltd.), Shanghai Pudong Development Bank, Industrial Bank, Ping An Bank, CEB (China Everbright Bank), Bank of Ningbo and Bank of Beijing as sample, the concrete classification of these 14 banks as shown in Table 3.

In view of the keynote of article is to make a comparative study of the effect of Yu'ebao on saving deposits of three kinds of commercial banks. Therefore, there's a need to build three positivism models to testify in this section.

$$
\begin{aligned}
& \operatorname{ckzzl}_{\mathrm{gy}}=\beta_{0}+\beta_{1} \text { yebsyl }+\beta_{2} \mathrm{CEI}+\beta_{3} \mathrm{szzszzl}+\beta_{4} \mathrm{CPI}+\beta_{5} \ln \mathrm{sxfl}+\beta_{6} \ln \mathrm{jgzzl}+\mu_{i t} \\
& \mathrm{ckzzl}_{\mathrm{gf}}=\delta_{0}+\delta_{1} \text { yebsyl }+\delta_{2} \mathrm{CEI}+\delta_{3} \mathrm{szzszzl}+\delta_{4} \mathrm{CPI}+\delta_{5} \ln \mathrm{sxfl}+\delta_{6} \ln \mathrm{jgzzl}+\mu_{i t} \\
& \mathrm{ckzzl}_{\mathrm{cs}}=\gamma_{0}+\gamma_{1} \mathrm{yebsyl}+\gamma_{2} \mathrm{CEI}+\gamma_{3} \mathrm{szzszzl}+\gamma_{4} \mathrm{CPI}+\gamma_{5} \ln \mathrm{sxfl}+\gamma_{6} \ln \mathrm{jgzzl}+\mu_{i t}
\end{aligned}
$$

Empirical results of three models are shown as Table 3.

It can be seen in Table 4 that the effect of Yu'ebao yield on saving deposits of various kinds of commercial banks is inconsistent. The effect of Yu'ebao on city commercial banks is maximum, yet on state-owned banks is minimum, which the case is probably due to multiple quantity, large cardinal of deposits and loyal clients of affiliated agency of domestic commercial banks. The effect of Yu'ebao will only generate small diminutive effect 
Table 2. Empirical results of the effect of Yu'ebao to the deposits.

\begin{tabular}{|c|c|c|c|c|c|c|c|}
\hline \multirow{2}{*}{$\begin{array}{l}\text { Independent } \\
\text { Variable }\end{array}$} & \multicolumn{7}{|c|}{ Dependent Variable } \\
\hline & ckzzl & ckzzl & ckzzl & ckzzl & ckzzl & ckzzl & yebsyl \\
\hline Constant & $\begin{array}{c}0.07 \\
(3.06)\end{array}$ & $\begin{array}{c}0.09 \\
(4.08)\end{array}$ & $\begin{array}{c}0.11 \\
(2.39)\end{array}$ & $\begin{array}{c}0.11 \\
(2.39)\end{array}$ & $\begin{array}{c}0.07 \\
(0.99)\end{array}$ & $\begin{array}{c}0.09 \\
(1.71)\end{array}$ & $\begin{array}{l}-0.04 \\
(58.6)\end{array}$ \\
\hline yebsyl & $\begin{array}{c}-1.77^{* * *} \\
(-4.09)\end{array}$ & $\begin{array}{c}-1.71^{* * *} \\
(3.96)\end{array}$ & $\begin{array}{c}-2.26^{* * *} \\
(3.70)\end{array}$ & $\begin{array}{c}-2.26^{* * *} \\
(3.70)\end{array}$ & $\begin{array}{l}-2.06^{* * *} \\
(-3.15)\end{array}$ & $\begin{array}{c}-2.15^{* * *} \\
(3.45)\end{array}$ & \\
\hline sxfl & $\begin{array}{l}13.64 \\
(1.89)\end{array}$ & $\begin{array}{c}6.58 \\
(1.76)\end{array}$ & & & $\begin{array}{c}8.47 \\
(0.91)\end{array}$ & $\begin{array}{c}4.74 \\
(1.22)\end{array}$ & \\
\hline jgzzl & $\begin{array}{l}0.17^{* *} \\
(1.95)\end{array}$ & $\begin{array}{c}0.23^{*} \\
(1.65)\end{array}$ & & & $\begin{array}{l}0.21^{* *} \\
(2.06)\end{array}$ & $\begin{array}{l}0.06^{* *} \\
(1.99)\end{array}$ & \\
\hline CEI & & & $\begin{array}{l}0.34^{* *} \\
(2.66)\end{array}$ & $\begin{array}{l}0.34^{* *} \\
(2.65)\end{array}$ & $\begin{array}{c}0.35^{* *} \\
(2.7)\end{array}$ & $\begin{array}{l}0.34^{* *} \\
(2.69)\end{array}$ & \\
\hline Szzzzl & & & $\begin{array}{l}-0.21 \\
(-0.24)\end{array}$ & $\begin{array}{l}-0.21 \\
(-0.24)\end{array}$ & $\begin{array}{l}-0.39 \\
(-0.44)\end{array}$ & $\begin{array}{c}0.32 \\
(-0.36)\end{array}$ & $\begin{array}{l}-0.54^{* * *} \\
(-3.23)\end{array}$ \\
\hline CPI & & & $\begin{array}{l}-0.18 \\
(-0.21)\end{array}$ & $\begin{array}{l}-0.18 \\
(-0.2)\end{array}$ & $\begin{array}{c}0.47 \\
(0.31)\end{array}$ & $\begin{array}{c}0.15 \\
(0.16)\end{array}$ & \\
\hline Effect Model & Fixed Effect & $\begin{array}{c}\text { Random } \\
\text { Effect }\end{array}$ & Fixed Effect & $\begin{array}{l}\text { Random } \\
\text { Effect }\end{array}$ & Fixed Effect & Random Effect & Fixed Effect \\
\hline $\mathrm{R} 2$ & 0.82 & 0.73 & 0.86 & 0.78 & 0.77 & 0.79 & 0.87 \\
\hline
\end{tabular}

Note: ${ }^{* * *},{ }^{* *}$ and ${ }^{*}$ represent significant level of $1 \%, 5 \%$ and $10 \%$, respectively, the same as below.

Table 3. Bank classification.

\begin{tabular}{|c|c|}
\hline The type of bank & The name of bank \\
\hline State-owned commercial bank & $\begin{array}{c}\text { ICBC, Bank of China Agricultural Bank of China, CCB, } \\
\text { Bank of Communications }\end{array}$ \\
\hline Joint-stock commercial ban & $\begin{array}{c}\text { China Merchants Bank, China CITIC Bank, CMBC, Shanghai Pudong } \\
\text { Development Bank, Industrial Bank, Ping An Bank, CEB }\end{array}$ \\
\hline City commercial bank & Bank of Ningbo, Bank of Beijing \\
\hline
\end{tabular}

Table 4. Statistical analysis results ${ }^{1}$.

\begin{tabular}{|c|c|c|c|c|c|c|c|c|c|}
\hline \multirow{2}{*}{$\begin{array}{c}\text { Independent } \\
\text { Variable }\end{array}$} & \multicolumn{9}{|c|}{ Dependent Variable } \\
\hline & $\mathrm{ckzzl}_{\mathrm{gy}}$ & ckzzl $_{\mathrm{gy}}$ & $\mathrm{ckzzl}_{\mathrm{gy}}$ & ckzzl $_{\mathrm{gf}}$ & $\mathrm{ckzzl}_{\mathrm{gf}}$ & ckzzl $_{\text {gf }}$ & ckzzl $_{\mathrm{CS}}$ & ckzzl $_{\mathrm{CS}}$ & ckzzl $_{\mathrm{CS}}$ \\
\hline Constant & $\begin{array}{c}0.00 \\
(0.003)\end{array}$ & $\begin{array}{l}0.086 \\
(1.57)\end{array}$ & $\begin{array}{l}-0.008 \\
(-0.09)\end{array}$ & $\begin{array}{c}0.09 \\
(2.46)\end{array}$ & $\begin{array}{c}0.10 \\
(1.23)\end{array}$ & $\begin{array}{c}0.08 \\
(0.85)\end{array}$ & $\begin{array}{c}0.09 \\
(0.17)\end{array}$ & $\begin{array}{c}0.24 \\
(1.71)\end{array}$ & $\begin{array}{c}0.29 \\
(1.34)\end{array}$ \\
\hline yebsyl & $\begin{array}{l}-1.11^{* *} \\
(-1.97)\end{array}$ & $\begin{array}{l}-2.25^{* * * *} \\
(-3.05)\end{array}$ & $\begin{array}{c}-1.54^{* * * *} \\
(-1.65)\end{array}$ & $\begin{array}{l}-1.96^{* * * *} \\
(-2.61)\end{array}$ & $\begin{array}{l}-1.76^{*} \\
(-1.74)\end{array}$ & $\begin{array}{l}-1.71^{*} \\
(-1.69)\end{array}$ & $\begin{array}{l}-1.91 \\
(-1.47)\end{array}$ & $\begin{array}{l}-4.04^{* * *} \\
(-2.22)\end{array}$ & $\begin{array}{l}-4.47^{* * *} \\
(-1.97)\end{array}$ \\
\hline sxfl & $\begin{array}{l}33.13^{* *} \\
(2.25)\end{array}$ & & $\begin{array}{l}21.69 \\
(1.22)\end{array}$ & $\begin{array}{l}10.71 \\
(1.04)\end{array}$ & & $\begin{array}{c}3.46 \\
(0.51)\end{array}$ & $\begin{array}{l}19.72 \\
(0.88)\end{array}$ & & $\begin{array}{l}-11.34 \\
(-0.26)\end{array}$ \\
\hline jgzzl & $\begin{array}{l}0.25^{* *} \\
(2.96)\end{array}$ & & $\begin{array}{l}0.22^{* *} \\
(2.79)\end{array}$ & $\begin{array}{c}0.18 \\
(0.65)\end{array}$ & & $\begin{array}{c}0.17 \\
(0.41)\end{array}$ & $\begin{array}{c}0.23 \\
(1.04)\end{array}$ & & $\begin{array}{c}0.15 \\
(0.34)\end{array}$ \\
\hline CEI & & $\begin{array}{l}0.46^{* *} \\
(3.00)\end{array}$ & $\begin{array}{l}0.44^{* *} \\
(2.87)\end{array}$ & & $\begin{array}{c}0.22 \\
(1.06)\end{array}$ & $\begin{array}{c}0.23 \\
(1.09)\end{array}$ & & $\begin{array}{c}0.44 \\
(1.15)\end{array}$ & $\begin{array}{c}0.45 \\
(1.14)\end{array}$ \\
\hline Szzzzl & & $\begin{array}{c}-0.76 \\
(-0.72)\end{array}$ & $\begin{array}{c}-0.85 \\
(-0.80)\end{array}$ & & $\begin{array}{c}0.59 \\
(0.41)\end{array}$ & $\begin{array}{c}0.48 \\
(0.32)\end{array}$ & & $\begin{array}{l}-1.66 \\
(0.64)\end{array}$ & $\begin{array}{l}-1.39 \\
(0.49)\end{array}$ \\
\hline CPI & & $\begin{array}{c}0.06 \\
(0.06)\end{array}$ & $\begin{array}{c}0.85 \\
(-0.68)\end{array}$ & & $\begin{array}{c}0.19 \\
(0.13)\end{array}$ & $\begin{array}{c}0.52 \\
(0.32)\end{array}$ & & $\begin{array}{l}-2.08 \\
(-0.79)\end{array}$ & $\begin{array}{l}-2.83 \\
(-0.81)\end{array}$ \\
\hline R2 & 0.58 & 0.66 & 0.41 & 0.45 & 0.47 & 0.48 & 0.41 & 0.38 & 0.38 \\
\hline DW & 2.33 & 2.48 & 2.41 & 2.18 & 2.82 & 2.63 & 2.72 & 2.79 & 2.78 \\
\hline
\end{tabular}

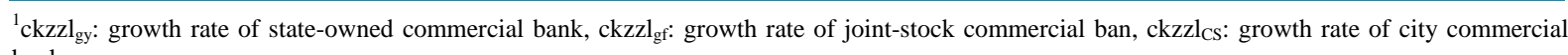
bank. 
on it in the short run. However, for the reason that the commercial banks is short of branch, the established time is short and the consumer has not formed sharply a certain loyalty. Consequently, the emerge of Yu'ebao takes up an enormous portion from its saving deposits.

\section{Conclusion}

The article takes Yu'ebao and the saving deposits of commercial banks as the research object. In the first place, it theoretically analyzes the reason for Yu'ebao to take up the saving deposits of commercial banks according to liquidity, investment profitability and investment risk. Then, it takes quarterly data from June 2013 to June 2015 of 14 banks as the research object, testifying the beingness of spin-off of Yu'ebao to saving deposits of commercial banks with the use of panel regression model. From empirical results, Yu'ebao has a negative effect on saving deposits of commercial banks, producing spin-off to saving deposits of commercial banks. At the same time, it can be seen that the spin-off business of Yu'ebao to saving deposits of commercial banks brings a significant effect according to analysis. The following paragraph will come up with matching policy suggestion according to research results.

\section{The Suggestion of Policy}

\subsection{Take Positivity Challenge, Promote Financial Innovation and Change Thought Patterns}

Traditional commercial banks must positively promote financial innovation and learn how to use internet thinking to inspect the market in the face of challenge. What Yu'ebao brings is not only the loss of partial saving deposits of commercial banks, but also brings a kind of thought patterns, which is an internet financial pattern. Commercial banks don't rule out the competition and they would like to learn from internet financial enterprises with an attitude of positivity and inclusion and perfect themselves constantly. Yu'ebao is nothing but the current competitor in the front rank, there will be more and more competitors in later period such as Jingdong financial etc products. Therefore, traditional commercial banks shall positively convert thought patterns and give great impetus to promote financial innovation in order to catch up forthwith and finally take the preemptive opportunities in the market.

\subsection{Focus on Customers and Construct Service Bank}

Traditional commercial banks shall break traditional thinking model and build a new idea of development of "focus on customers". The success of Yu'ebao is the result of long tail theory, which is accumulate all nonmainstream markets together to form a bigger market than popular market. Alibaba Group possesses a large number of long tail users, and they understand how to analyze through big data in order to use the idel debris money to ultimately benefit from it. The design of Yu'ebao is lively and humanized, which is exactly the interpretation of internet financial enterprises to focus on consumers to provide products and service. Commercial banks shall further emphasize the core status of customer demand and customer experience in service, to service for individual needs of customer, to set up different product classification based on different clients, to provide more and more targeted service as market-oriented and to enhance service level and service awareness in order to the satisfaction of clients to service and product of commercial banks.

\subsection{Bring in Technology Talents and Pay Attention to Big Data Analysis}

The success of Yu'ebao profits from the fund company bringing a large number of users on e-commerce platform into big data analysis, differentiated demand of different customer is analyzed according to modeling analysis, it reflects the customer demand as well as reduce the risk to minimum according to evaluation analysis. Therefore, if commercial banks intend to make a breakthrough, the position and role of big data shall be attached importance to. On the one hand, commercial banks shall collect all aspect information of clients by means of technology means, use data mining technology to classify the information, continuously learn from the experience of data mining application etc aspects of internet enterprises, to promote themselves to comprehensive handling ability of various information and finally form data system of commercial banks. On the other hand, the competition of internet finance, after all, is talent competition. Commercial banks shall actively culti- 
vate multiaspect talents who get the hang of big data analysis ability. And not only attach importance to recruit professional senior engineers with internet technology background, but also formulate professional training program at regular intervals at work, and then cultivate a large number of talents who acclimatize themselves to the development of banking industry and ultimately form the core competition of commercial banks in internet financial field.

\section{References}

[1] Sheng, S.C. and Zhang, X. (2014) Yu'ebao and Management of Reserves against Deposit. Financial Times, 2014-0319.

[2] Xie, P. and Zou, C.W. (2012) Research of Internet Financial Pattern. Financial Research, No. 12, 11-22.

[3] Qiu, X. (2013) The impact and Enlightment on Commercial Bank. New Finance, No. 9, 50-54.

[4] Niu, W.X. (2012) Yu'ebao Bulldozes Your Wallet Rather than Banks. Financial Research, No. 12, 15.

[5] Gao, S.W. (2014) Yu'ebao Will Not Lift up Loan Interest Rate. China Merchant Securities News, 2014-03-24. 